\title{
Ensaios pedagógicos
}

\author{
JulianeA p. dePaula Perez CAMPOS ${ }^{1}$
}

ENSA IOS PEDAGÓGICOS. Brasília: Ministério da Educação, Secretaria de Educação Especial, 2007. 194p.

A obra "Ensaios Pedagógicos", organizada pela Secretaria da Educação Especial, reúnereflexões de pesquisadores nacionais einternacionais sobrequestões educacionais e sociais relacionadas à educação inclusiva; fruto de palestras apresentadas no IV Seminário Nacional do Programa Educação Inclusiva: direito à diversidade.

Quais os avançose impasses da educação inclusiva? O quese podeaprender da história recente dos diferentes paradigmas que nortearam (e norteiam) a educação especial? Qual o cenário real de inclusão encontrado em nossas escolas? O que significa viver numa sociedade inclusiva? Considerações a essas questões são apresentadas criteriosamente no livro, permitindo ao leitor refletir sobre a real idadeeducacional das pessoas com necessidades especiais no Brasil, delimitada por uma política ainda pouco pautada no direito à igual dade ena valorização das diferenças.

Neste sentido, os 22 ensaios que compõem o livro sinalizam claramente a necessidadedeuma nova política nacional de educação especial, condizentecom os princípios da educação inclusiva; levando-se em conta não só o alunado com necessidades educacionais especiais, mas também o trabal ho docente, as práticas pedagógicas, a ressignificação da escola comum, a equiparação deoportunidades, dentre outros aspectos.

Em síntese, esta obra destaca-se pelas seguintes temáticas: movimentos, desafios e perspectivas da educação inclusiva; exclusão e resistência a uma pedagogia diferenciada; formação continuada de professores; políticas públicas de combateà exclusão; o acesso ao mercado de trabal ho da pessoa com deficiência;

${ }^{1}$ Doutora em Educação Especial. Professora do Centro Universitário Claretiano/ CEUCLAR julianepaula@hotmail.com 
direitos constitucionais, desenvolvimento da autonomia, independência e emanci pação da pessoa com deficiência. Há ainda duas temáticas que tratam respectivamente da educação de al unos com características dealtas habilidadese a inclusão desurdos, sendo discutidas as necessidades prioriotárias a estes alunos, seja através de oportunidades educacionais adequadas aos seus interesses e competências, seja na garantia deuma educação dequalidadena língua desinais.

Com isto, o leitor terá, em uma única obra, uma variedade de subtemas, possibilitando diferentes leituras sobre o fenômeno da inclusão. Leituras estas permeadas de revisões bibliográficas atuais, relato de experiências e pesquisas que vêm sendo desenvolvidas nas diferentes regiões do Brasil, etambém em Portugal. Além disto, ainda com a oportunidade de ter a obra completa em CD-rom que acompanha o livro.

Enfim, éuma obra quenão pode deixar deser estuda por aqueles envolvidos com a pesquisa e com as práticas pedagógicas e sociais que integram a área da educação especial. 